\title{
Pot tovarn kot pripoved o dediščini ribištva in predelovalne industrije s poudarkom na Izoli
}

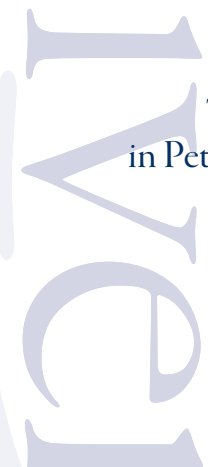

Tereza Prešeren (študentka), Alenka Janko Spreizer, Nataša Kolega

in Petra Kavrečič, Univerza na Primorskem, Fakulteta za humanistične študije

Srečko Gombač, Društvo Histrion

Pričujoči članek predstavi bralcu Pot tovarn oziroma pripoveduje bralcu/obiskovalcu zgodbo, ki jo je gospodarska dejavnost ribje predelovalne industrije pustila za seboj od zadnje četrtine 19. stoletja do današnjega časa. Pot pripoveduje zgodbo, ki se med Izolani še danes ohranja, živi naprej in predstavlja spomin na šest tovarniških obratov mesta Izole, postavljenih vse od zahodnega do vzhodnega zaliva mesta Izola. Skrajni dve točki poti sovpadata s primarno gospodarsko dejavnostjo mesta Izole, tj. predelavo male $\gg$ plave $\ll$ ribe.

Ključne besede: Pot tovarn, Študentski inovativni projekt za družbeno korist (ŠIPK), Riba na poti, kulturna dediščina, ribištvo in predelovalna industrija, Izola.

The present article presents the reader the Path of Factories or tells the reader/visitor the story left behind the former economic activity of the fish processing industry, operating from the last quarter of the Igth century to the present day. The path tells the story, which is still preserved today among Isolans, lives on and represents the memory about six factory plants in the city of Izola/Isola, which are placed all along the the way from the west to the eastern bay of the town. The two extremes of the route coincide with the primary economic activity of the city of Izola/Isola, processing small „blue “ fish.

Keywords: The track of factories, Students innnovative projects for social benefit (ŠIPK), fish on the way, cultural herritage, fisheries and fishing, food processing industries, Izola.

\section{Pot tovarn in projekt Riba na poti}

$\mathrm{V}$ okviru Študentskega inovativnega projekta za družbeno korist ŠIPK - »Riba na poti, riba napotí: dediščina ribištva in predelovalne industrije s poudarkom na Izoli $\ll$, ki je potekal od marca do junija 2018 , je nastalo več tematskih poti $\mathrm{z}$ interaktivnimi zemljevidi in opisom točk. Namen projekta je bil prispevati h kulturnemu turizmu in med drugim preko oblikovanja poti prispevati $\mathrm{k}$ oživljanju spomina na nekdanjo gonilno silo Izole, tj. na tovarne ribjih konzerv in predelovalno prehrambno industrijo. Oblikovali smo turistične itinerarije $\mathrm{v}$ Izoli in njeni okolici, ki so poveza- ni z vsakdanjim življenjem ribičev in delavk $\mathrm{v}$ tovarnah ribjih konzerv in predelave hrane. Preko Poti tovarn, Poti škverov, Poti fabrkink in Poti San Dona tako prispevamo k poznavanju zgodovine, geografije, kulture ter vsakdanjega načina življenja ribičev in delavk. Poleg tega želimo prispevati $\mathrm{k}$ valorizaciji in promociji ribištva in predelovalne industrije rib kot dela nacionalne ter predvsem regionalne dediščine, ki je vezana na obmorski prostor današnje Republike Slovenije in je umeščena $v$ čas političnih in družbenih transformacij nekdanjih držav »Avstrije «, Italije, Jugoslavije in Slovenije (19., 20. in 21. stoletje). Slovensko primorje z zaledjem se geografsko umešča v Istro in Sredozemlje in sodi med 
najzanimivejša multikulturna območja. To območje na stičišču romanskega, germanskega ter slovanskega sveta je bilo v preteklosti izpostavljeno pogostim spremembam političnih oblasti in konfliktom, kar je sprožilo številne migracije prebivalstva. Obmorski kraji imajo za različne prebivalce več pomenov, saj imajo bogato, a hkrati tudi sporno ali zamolčano zgodovino. Tak primer predstavljata ribištvo ter predelovalna industrija rib v Sloveniji, ki jima ni bilo posvečeno dovolj pozornosti, zlasti v primerjavi z raziskovanjem ribištva na Tržaškem. Oblikovane poti govorijo o značilnostih načina življenja in dela ljudi, ki (so) se ukvarjali z ribištvom in predelovalno industrijo rib.

Med drugim je nastala tudi Pot tovarn. Opis te poti je nastal kot skupno delo študentke zgodovine Tereze Prešeren, pedagoških mentoric izr. prof. dr. Alenke Janko Spreizer, doc. dr. Nataše Kolega, doc. dr. Petre Kavrečič in strokovnega sodelavca iz društva Histrion, Srečka Gombača.

Še danes živ spomin na obdobje delovanja tovarn ribjih konzerv lahko v Izoli spremljamo tudi v prostoru, ki ga mnogi obiskovalci dojamejo kot devastirane lokacije, saj v priobalnem pasu vidimo propadle tovarniške stavbe ali njihove ostanke (ruševine). Spomin se ohranja torej v obmorski krajini kot tudi v pripovedih Izolanov, ki pa jih mnogi obiskovalci ne morejo slišati. Pot tovarn torej predstavi zgodbo, ki jo je pretekla gospodarska dejavnost ribje predelovalne industrije pustila za seboj. Zgodbo, ki se med ljudmi starejše generacije še ohranja, se predaja in živi naprej ter predstavlja naracije o šestih tovarniških obratih mesta Izole, postavljenih vse od zahodnega do vzhodnega zaliva mesta.

\footnotetext{
$\mathrm{V}$ projektu so poleg navedene študentke, pedagoških mentoric in strokovnega sodelavca sodelovali tudi Ivana Riganova (marec), UP FHŠ, študentka kulturnih študijev in antropologije (2. stopnja); Katarina Barbara Reberc (april-junij) UL FKKT, študentka kemije, I. stopnja; Artur Steffe, UP FHŠ, študent dvopredmetnega študija antropologije in geografije, I. stopnja; Hana Hanžek-Turnšek, UP FAMNIT, študentka biodiverzitete, I, stopnja; Lan Rak in Katja Masten, oba UP FTŠ, študenta managementa turističnih podjetij, visokošolski program, I. stopnja, ter Andrej Sitar, UP FHŠ in FTŚ, študent dediščinskega turizma, 2. stopnja. Pri projektu je za administrativno plat izvedbe skrbela sodelavka Karin Bandelj.
}

Skrajni dve točki poti sovpadata s primarno gospodarsko dejavnostjo mesta Izole, tj. predelavo male »plave« ribe. Lokacija postavitve te ali one tovarne je bila tako del strateškega premisleka, kako v čim krajšem času pridobljen ulov tudi predelati, saj so nekoč uporabljali za transport predvsem ladje in poti po morju. $\mathrm{Z}$ arhitekturnega vidika so večje tovarne, Ampelea (Delamaris), Arrigoni (Argo oziroma Droga) ter Degrassi (ali pozneje podjetje Riba), ki so bile postavljene izven starega mestnega jedra, še danes opazne v zasnovi Izole, medtem ko se lokacij ostalih tovarn $\mathrm{v}$ prostoru ne da opaziti na prvi pogled.

\section{Tovarna Ampelea - Delamaris}

Zgodba tovarne Delamaris se je začela leta I879, ko je Émile Louis Roullet, uspešen francoski gospodarstvenik, postavil prvo tovarno za predelavo male plave ribe v mestu Izola (Volpi Lisjak 200I, 135). Že v začetku svojega delovanja je tovarna zaposlovala sto delavk (Tomšič 2002, 137).Tovarna je najverjetneje obstajala $v$ naslednjih štirih letih pod imenom Émile L. Roullet et CO., prodajala pa pod imenom De Saint Ange et CO (Volpi Lisjak 200I, 136).

$\mathrm{V}$ naslednjih nekaj letih je tovarna doživela velike tržne uspehe in Roullet je leta $1883 \mathrm{z}$ vzpostavitvijo delniške družbe Société Générale Française de Conserves Alimentairies C. A. razširil tovarniški kompleks (Tomšič 2002, I38).Tovarna je ob vzpostavitvi delniške družbe že obsegala 4,7 ha zemeljske površine ter 22,12 ha vodnih površin (morska laguna in močvirje). Delniška družba je prevzela vodenje tovarne 2I. januarja I883. Ustanovitelj delniške družbe, Émille Louis Roullet, pa je tako dobil v last 240 delnic po 500 frankov (Volpi Lisjak 2001, 136).

$$
\begin{aligned}
& \text { Tej tovarni so rekli fabrika, dei frančezi‘, rekli } \\
& \text { so ji tudi fabrika, aibani '. Namreč to je tovar- } \\
& \text { na, ki je stala v bližini izvira mineralne vode, } \\
& \text { termalne vode v predelu ob cerkvici svete- } \\
& \text { ga Petra, to je na vzhodnem delu izolske- } \\
& \text { ga, nekdanjega izolskega otoka. In tu so, tu } \\
& \text { je ta Francoz Roullet postavil prvo tovarno. } \\
& \text { (Intervju s Srečkom Gombačem, arhiv dru- } \\
& \text { štva Histrion) }
\end{aligned}
$$




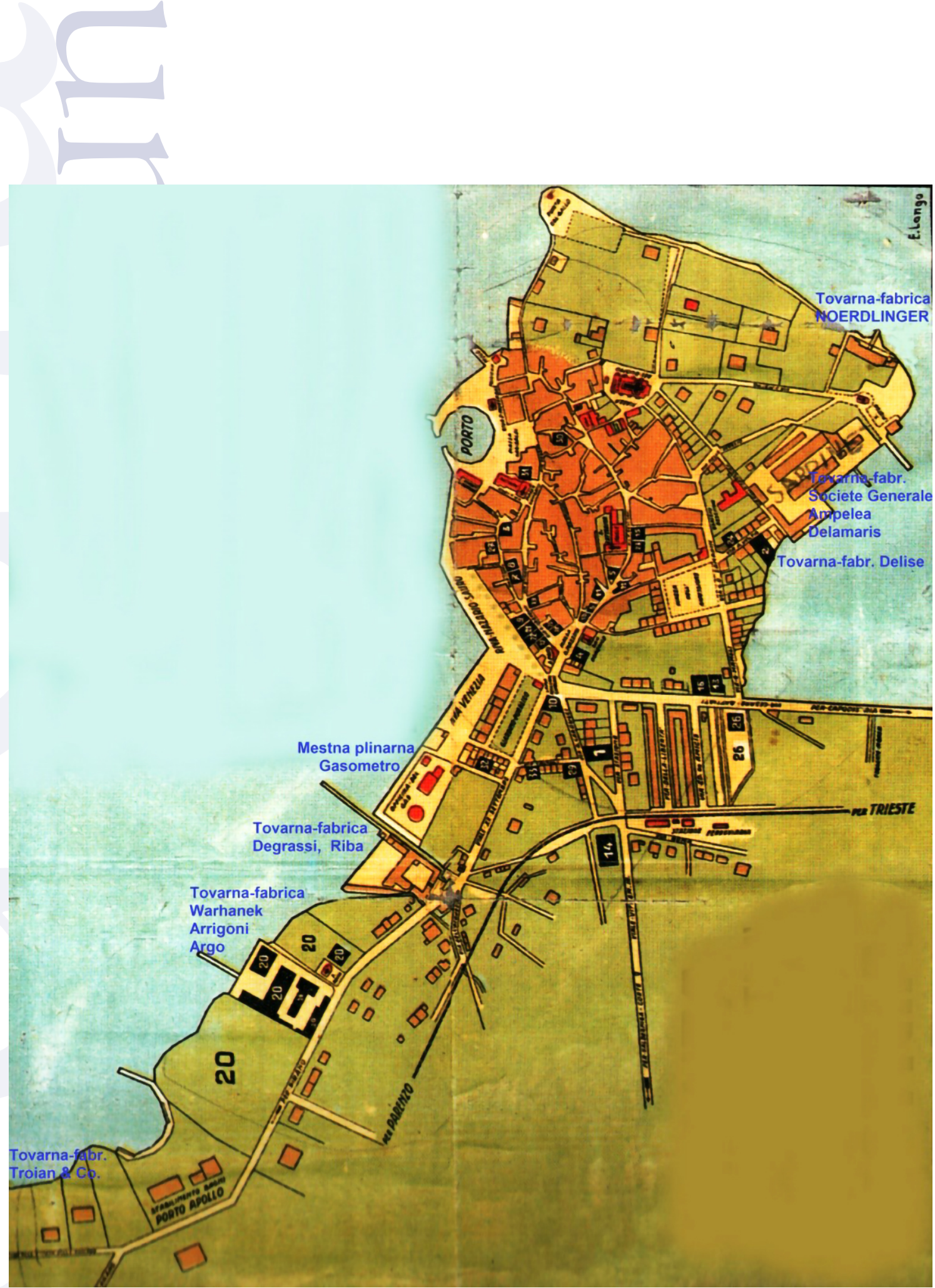

Slika I: Ilustrativni zemljevid tovarn v mestu Izola (Vir: Arhiv društva Histrion)

Leta I 888 je tovarna dobila dovoljenje za razširitev tovarniškega kompleksa. Ob morju so bili najprej postavljeni proizvodna hala, pristajal- ni pomol ter še nekaj manjših zgradb. Arhitekt Eugenio Marchetti je pozneje zasnoval osrednjo stavbo za proizvodnjo hrane in skladišče. Zraven 
pa je bilo postavljenih še nekaj drugih obratov za predelavo hrane, hala za izdelavo sodov in drugih mizarskih izdelkov, skladiščne hale ter hiša za osebje in hlev. Vse skupaj je tvorilo funkcionalno zasnovano celoto. Marchetti je racionalno zasnovo tovarniškega kompleksa omilil s tradicionalnimi elementi klasicizma, vidnimi na fasadi (pročelju) tovarne (poudarjenost polj, ritmičnost stavbnih odprtin). Bogat finančni status tovarne se je kazal tudi z opečnatimi dimniki (Tomšič 2002, 138). Konec 19. stoletja sta tovarni Ampelea in Arrigoni skupaj zaposlovali 760 delavk, malo več kot 200 ribičev in 26 pomorščakov, ki so se ukvarjali s prevozom izdelkov (Kramar 1987, 309).

Leta 1892 je tovarno prevzela anglo-avstrijska banka s sedežem v Trstu. Francoska delniška družba je tako dobila novega lastnika in tudi novo ime - Usines de l'Ancienne Société Générale Française de Conserves Alimentairies. Starega imena tovarne novi lastniki niso bistveno spreminjali, v strahu pred izgubo odjemalcev po celem svetu. Dodali so mu zgolj Usine de l'Ancienne, kar $\mathrm{v}$ prevodu pomeni stare tovarne (Volpi Lisjak 200I, 137). Tovarna je razširila svojo proizvodnjo konzerviranja hrane še na sadje (slive), zelenjavo (grah, fižol, paradižnik) in goveje meso (Kramar I987, 309). Za namene širitve proizvodnje so bili postavljeni še klavnica in hlevi, tovarna pa je dobila tudi svojo t.i. lokomobilo. Doživela je nov razcvet. Postala je glavni dobavitelj hrane za avstroogrsko vojsko, svoj izvozni trg pa je razširila tudi v Rusijo, v Ameriko ter na Bližnji Vzhod (Tomšič 2002, 138).

\footnotetext{
In leta 1915 so se vse te aktivnosti pravzaprav skoraj ugasnile, zaradi tega, ker je v teh krajih divjala prva svetovna vojna. Prva svetovna vojna je prinesla strahovite spremembe $v$ te kraje. Namreč, že to dejstvo, da je bila tu v bližini vojna, je pomenilo, da so ljudje pač trpeli lakoto in družba je postala neorganizirana ravno zaradi tega, ker se med vojno pač ne da normalno funkcionirat. In po prvi svetovni vojni je bil ta teritorij priključen kraljevini Italiji. /.../ je prišlo do zamenjave kapitala. Avstrijci so svoje premoženje prodali
}

\section{novim gospodarjem, ti novi gospodarji pa so postali ... v primeru/prej/francoske tovar- ne je to postala pač družba, ki se je imeno- vala Società Conservifici in ta družba je tovar- ni dala ime Ampelea. (Intervju s Srečkom Gombačem, arhiv društva Histrion)}

Med leti 1918 in 1920 je tovarna, zaradi posledic prve svetovne vojne, prekinila s svojim delovanjem (Volpi Lisjak 200I, 138). Leta I920 jo je, poleg še nekaj drugih izolskih tovarn, nato prevzelo tržaško podjetje Conservifici S.A. (Tomšič 2002, 139). Italijanski prevzem industrijskih obratov je bila posledica leta 1920 sklenjene Rapalske pogodbe med Kraljevino Italijo in Kraljevino Srbov, Hrvatov in Slovencev, po kateri je bila končno določena nova meja med državama. Slovensko Primorje, del Dolenjske in del Notranjske so po novem postali del italijanskega državnega ozemlja.

Konec dvajsetih let dvajsetega stoletja je arhitekt Romitta zasnoval nove vhodne stavbe, ki stoji še danes, ter poslovnih objektov za in ob njej. Stavba je bila zasnovana v klasicističnem stilu (dvoetažni vhodni atrij z dvignjenim fasadnim timpanonom in simetričnima stavbnima kriloma) z oblikovnimi elementi italijanskega modernističnega gibanja (širok polkrožni vhodni portal, zvišana polkrožna vhoda ob strani glavnega vhoda). Leta 1930 je tovarna ponovno dobila novo ime - tovarna Ampelea S. A. Conservifici. $\mathrm{V}$ naslednjih letih je prišlo do modernizacije in adaptacije starih objektov ter gradnje novih. Poseben tehniški dosežek predstavlja šestnajst metrsko strešno predalčje, ki zaključuje skladišče (Tomšič 2002, 139).

$\mathrm{V}$ medvojnem obdobju je začela Ampelea tudi s pridelavo ribje moke in ribjega olja, marmelade, paradižnikov mezge, ter konzerviranjem zelenjave, slanih filetov inčunov ter raznih paštet. Tik pred začetkom druge svetovne vojne je tovarna zaposlovala kar I200 delavcev, po večini žensk iz zaledja Izole, proizvedla pa je kar I 4 milijonov konzerv na leto (Volpi Lisjak 200I, 139):

Z jugoslovanskim prevzemom oblasti $\mathrm{v}$ Slovenskem primorju maja leta 1945 se je obra- 
Evakuacija je obsegala: a) $50 \%$ vseh strojev za izdelavo pločevinaste embalaže $\mathrm{z}$ vsem pripadajoči orodjem, transmisijami, električnimi motorji itd., b) $50 \%$ ali več surovin, c) celotno ribiško floto, č) celotne hladilnice, d) ostale stvari, ki bi lahko konkurirale jugoslovanski konzervni industriji (Kramar 1992, 176-178).

Zaradi odvzete flote je začela tovarna delovati v svoji okrnjeni obliki, svoje surovine pa pridobivati s strani zasebnih ribičev ali ribolovnih podjetij, izolskega podjetja Riba in piranskega Ribiča. Istega leta je bila tovarna tudi preimenovana v tovarno Ex-Ampelea. Devet let kasneje, leta 1956 , pa je tovarna ponovno dobila novo ime - Iris (Terčon 1989, I23-I25).

Tri leta kasneje, leta 1959 so ustanovili Kombinat konzervne industrije Delamaris (KKID), v katerem so se zaradi lažje organizacije proizvodnje in prodaje izdelkov združili Iris, Argo, Ikra in leta 1952 ustanovljeno podjetje Delamaris export-import. Proizvodnja tovarne Iris (Ampelea) se je takrat dokončno usmerila $\mathrm{v}$ predelavo in konzerviranje rib (Terčon 2013, 124).

Ime Delamaris je nastalo kot zloženka delov imen nekdanjih treh velikih tovarn na današnjem slovenskem obmorskem prostoru: DEL po tovarni De Langlade iz Kopra, AM po tovarni Ampelea, AR po tovarni Arrigoni in IS po mestu Izola (Isola), vedo povedati delavke, ki so v času združevanja delale $\mathrm{v}$ omenjenih tovarnah. Simbolizirale so ga poleg značilnega logotipa napisa še tri ribice. Danes novi logotip Delamarisa ponovno uporablja ribico, tokrat le eno samo.

Tovarna je konec osemdesetih let dvajsetega stoletja s procesom modernizacije in izgradnje novih objektov izgubila osrednjo stavbo in skladišče iz leta I888. Kljub predelavi pa je tovarniški kompleks ohranil svoje pomembnejše arhitekturne značilnosti (na primer vhodna stavba) (Tomšič 2002, I 40).

Leta 1992 se je (po številnih delitvah, združitvah in prestrukturiranjih, do katerih je prišlo zaradi reforme o samoupravljanju sredi sedemdesetih let) oblikoval Holding Delamaris, ki je združeval podjetja Delsar, Riba, Delmar, Lera in Frigomar. Tovarna in vsa podjetja, povezana $z$ njo, so dobila tudi svoje, še danes dobro poznano ime Delamaris (Volpi Lisjak 200I, I39).

\section{Tovarna Delise}

Zapisi iz leta 1925 že govorijo o vzpostavljeni tovarni Delise v Izoli, ki je delovala na območju vzhodnega zaliva mesta Izole. Točne letnice začetka delovanja ne poznamo (Kramar 1987, 423). Postavljena je bila malo pred tovarno Ampelea na današnji Zustovičevi ulici. Kot nam je znano iz zapisov, jo je vzpostavil Italijan Nicolo Delise (Terčon 1989, I25). Po obsegu je šlo za majhen tovarniški obrat, saj je $\mathrm{z}$ devetimi zaposlenimi delavci proizvedla zgolj $13.000 \mathrm{~kg}$ različnih konzerv na leto (Kramar, prav tam). Za primerjavo lahko vzamemo tovarno Ampelea, ki je v enem letu proizvajala ioos ton konzerv (Kramar 1987, 424).

\section{Tovarna Noerdlinger}

Tovarna Noerdlinger je bila postavljena leta I884, prav tako na območju vzhodnega zaliva mesta Izola, malo naprej od tovarne Ampelea, blizu križišča današnje Ulice Svetega Petra in Ulice ob pečini oziroma $v$ bližini porušene cerkvice Svetega Petra. Tovarno je ustanovila tržaška delniška družba Ditta $B$. Noerdlinger e fratello da Trisete, ki sta jo vodila brata Noerdlinger, njena dejavnost pa je bila usmerjena $\mathrm{v}$ konzerviranje sliv. Leta 1888 je tovarna povečala tovarniške prostore, vendar ni znano za koliko. Leta I9I2 je tovarna zaposlovala 86 delavcev (Kramar 1987 , 309-310).

Leta 1920 je bila med kraljevino Italijo in kraljevino Jugoslavijo podpisana Rapalska pogodba, po kateri je slovenski del Primorja pripadal Italiji. Največje industrijske obrate v Izoli prevzela italijanska družba S. A. Conservifici. Novi lastnik je poleg tovarne Noerdlinger prevzel še tovarni Degrassi in Torrigiani, ki jih je priključil ali tovarni Ampelea ali Arrigoni, odvisno kako blizu je bila manjša tovarna eni ali drugi lokaciji obeh večjih tovarn (Volpi Lisjak 2001, 138; Terčon 1989, 123-135). 


\section{Tovarna Degrassi - Torrigiani}

\section{- Podjetje Riba}

Tovarno Degrassi je leta I882 postavil Giovanni Degrassi na območju zahodnega zaliva mesta Izole, med tovarno Arrigoni in kasnejšim podjetjem Riba (Terčon 2013, I25). Danes nedaleč stran stoji Izolanom dobro poznani bar Moby Dick, ali nova hiša pic - Cassa della Pizza. Proizvodni proces tovarne Degrassi je bil manjšega obsega in je leta 1912 zaposloval le 68 delavcev, večinoma žensk. Usmerjena je bila v konzerviranje male » plave « ribe in graha (Kramar 1987, 309310). Do sredine dvajsetih letih prejšnjega stoletja je bila tovarna preimenovana $v$ tovarno Torrigiani in je bila tako kot še nekaj drugih priključena tovarniškemu obratu Arrigoni (Kramar 1987, 423; Volpi Lisjak 200I, I38).

Prostore tovarne Torrigiani je v času po drugi svetovni vojni prevzelo na novo vzpostavljeno podjetje Riba d.d., ki se je ukvarjalo z ribolovom. Novo podjetje je nastalo v kritičnem povojnem obdobju, ko sta tovarni Arrigoni in Ampelea izgubili svoji ribiški floti, posledično pa tudi dostop do vira surovin za svoje konzerve. Podjetje je večkrat spremenilo tudi svoje ime. Med leti 1948 in 1954 je delovalo pod imenom $\gg$ RIBA - Tržaška ribarska družba in trgovina z ribami d.d.《. Leta 1954 je bila preimenovana $\mathrm{v} \gg$ RIBA Izola $\ll$ in ohranila je svoje ime do leta 1962, ko je začela poslovati v sklopu KKID (Kombinat konzervne industrije Delamaris) in DO DROGA (Terčon 1989, 125).

\section{Tovarna Arrigoni}

Tovarna je nastala leta I88I v zahodnem delu zaliva, v predelu Sv. Lovrenca. Postavil jo je dunajski podjetnik Carel Warchanek (Tomšič 2002, I3I). Tekom osemdesetih letih I9. stoletja so začeli poleg male plave ribe predelovati gnoj iz ribjih odpadkov ter bosanske slive $\mathrm{v}$ marmelado (Terčon 2013, I2I).

Svojo osnovno prostorsko zasnovo je tovarna dobila leta $1888 \mathrm{z}$ oblikovno enotnimi načrti arhitekta in inženirja Eugenia Marchettija, ki je snoval tudi tovarniški kompleks Ampeleje (glejte zgoraj, poglavje 2). Zasnova je temeljila

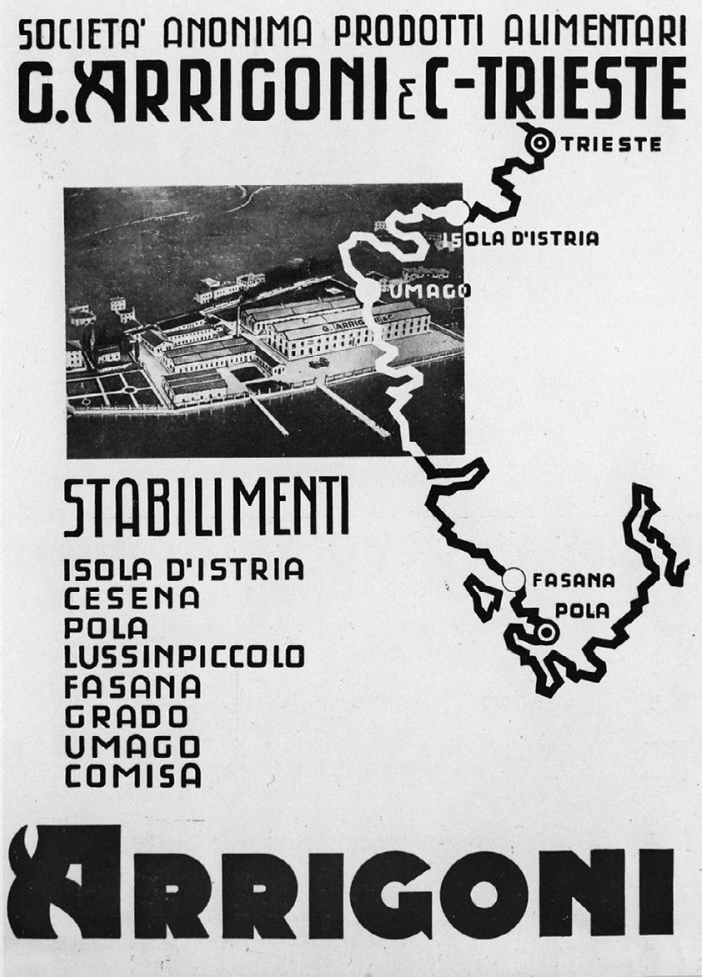

Slika 4: Tovarna Arrigoni v pred drugo svetovno vojno in njene široke gospodarske povezave od Trsta do Pule (Vir: Arhiv društva Histrion)

na treh podolgovatih halah, ki so bile namenjene osebju, proizvodnji, delavnicam in skladiščenju. Kompleks je predstavljal racionalno industrijsko arhitekturo z oblikovnimi prvinami klasicističnega stila. $\mathrm{Na}$ mestu stare tovarniške zgradbe iz leta I88I je bila postavljena nova osrednja podolgovata proizvodnja hala, krita s korci (Tomšič 2002, I3I-I32).

Leta 1912 je tovarna zaposlovala 200 delavcev (Kramar 1987, 310). Prva svetovna vojna je sicer močno prizadela delovanje tovarne, vsekakor pa so dvajseta leta dvajsetega stoletja zanjo pomenila popoln preobrat. Pod vodstvom tržaškega podjetja Società Anonima Prodotti Alimentari G. Arrigoni \& CO. in G. Sanguinettija je tovarna doživela pospešen razvoj in je postala največja tovarna v Istri. 
Leta 1925 je tovarna dobila svoje bolj poznano ime Arrigoni (Terčon 1989, I23-135). Svojo proizvodnjo so razširili na proizvajanje jušnih kock in antipaste (Kramar 1987, 423). V času dvajsetih let dvajsetega stoletja je tovarna dobila tudi svojo električno napeljavo, agregat in vodovodno napeljavo (Tomšič 2002, 132).

Novo vodstvo tovarne je prineslo snovanje nove proizvodna hale - osrednje arhitekture tovarniškega kompleksa. Tržaška projektanta B. Luignani in P. Bencian sta pri snovanju uporabljala takrat sodobne trende projektiranja, ki se kažejo skozi organizacijo prostorov in tehnologijo konstrukcije (dvoetažna železobetonska konstrukcija, stoječa na stebrih). Pri snovanju so prav tako opazni vplivi klasicistične tradicije (kompozicija in oblikovanje detajlov). Nova tovarna je bila odprta leta 1927 , na njeno otvoritev pa je prišel celo podpredsednik Italije (Tomšič 2002, I32):

$$
\begin{aligned}
& \text { Na drugi strani, tam kjer je bla pa tovarna, } \\
& \text { ki jo je postavu Warchanek, je pa nov last- } \\
& \text { nik biu italijanski državljan, ki mu je blo } \\
& \text { ime Sanguineti. Sanguineti je biu pa last- } \\
& \text { nik blagovne znamke Arrigoni. Arrigoni je } \\
& \text { stara blagovna znamka še iz sredine ig. sto- } \\
& \text { letja, ukvarjali pa so se predvsem z mesom. } \\
& \text { Oni so imel sedeže v Genovi in so uvažal } \\
& \text { meso iz Avstralije in ga potem distribuiral na } \\
& \text { italijanskem trgu. No in očitno je ta gospod } \\
& \text { Sanguineti videl nekako en razvojni poten- } \\
& \text { cial tudi v tem, da proizvaja ribje konzerve } \\
& \text { in je v ta namen potem pač v Izoli izjemno } \\
& \text { povečal tovarniške zmogljivosti. Tako da je } \\
& \text { ta tovarna konec } 20 \text {-ih let začela z novim el- } \\
& \text { anom in v bistveno večjem obsegu proiz- } \\
& \text { vajat kot je to pač počela prej.« (Intervju s } \\
& \text { Srečkom Gombačem, arhiv društva Histri- } \\
& \text { on) }
\end{aligned}
$$

Trideseta leta dvajsetega stoletja so prinesla reprezentančno urejanje kompleksa. Novozgrajeni tovarniški menzi ob cesti je sledila ureditev in gradnja reprezentančne ulične fasade $\mathrm{z}$ vhodnimi poslovnimi prostori, tj. gradnja dominantnega vhoda $\mathrm{z}$ upravnimi prostori, ki jo lahko opazujemo še danes. Leta 1936 je Luciano Marsico (Edilizia, Strade, Cementi) zasnoval levi trakt, temu pa je leta 1938 sledilo še snovanje desnega trakta pod vodstvom Dott. Ing. Rodolfa Coppe (Studio d'ingegneria civile, Impresa di construzione Trieste) (Tomšič 2002, 132). Enoten videz vhoda sestavljata dva polkrožno zaključena zrcalno postavljena traktata $\mathrm{z}$ ravno streho, ki se zaključi z dvignjeno odprto teraso in sklenjeno polkrožno betonsko konstrukcijo. Trakta spoštujeta ulično linijo, ob njima pa se prostor odpira v širok vhodni porton. Razgibana površina fasade dvoetažnih vhodnih objektov odseva notranjo funkcijo in ustroj prostorov. Višino stavbe še posebej poudarjajo visoki okenski in vratni segmenti. Okna etažnega dela so nižja kot okna zgornjih poslovnih prostorov. Zasnova predstavlja hkrati umirjeno in razgibano celoto, ki spaja funkcionalistično snovanje z umetniško rešitvijo. Vhodni arhitekturni objekt predstavlja prelom od tedaj aktualne režimske fašistične in italijanske nacionalistične arhitekture.

Štirideseta leta dvajsetega stoletja so prinesla izgradnjo polkrožne kurilnice $z$ optičnim videzom sakralnega objekta, šestdeset metrov visokega tovarniškega dimnika in pritlično skladišče za les z nazobčano strešno strukturo. Kurilnica optično spominja na sakralni objekt, v njej pa še leta 2002 stal originalni kurilni kotel iz konca tridesetih let. Dimnik je še danes jasen akcent izolske krajine, ki simbolizira gospodarski uspeh tovarne svoje dobe (Tomšič 2002, 133).

Konec druge svetovne vojne je prinesel menjavo oblasti in politično nestabilnost. Izola je kot del svobodnega tržaškega ozemlja spadala pod jugoslovansko cono B. Evakuacija strojev za izdelavo pločevinaste embalaže, orodja, večjega dela surovin, hladilnic, ribiške flote in ostalih premičnin leta 1947 so spremljale tudi kaotične razmere $\mathrm{v}$ delovanju tovarne. Ukinjen nadzor na vratih, konec zaklepanja skladišč in splošno pomanjkanje sta pomenila pogosto odnašanje kakšne konzerve ali nekaj rib s strani zaposlenih. Poleg tega je bil v veliki meri opuščen tudi računovodski nadzor, zaradi česar je tovarna poslova- 


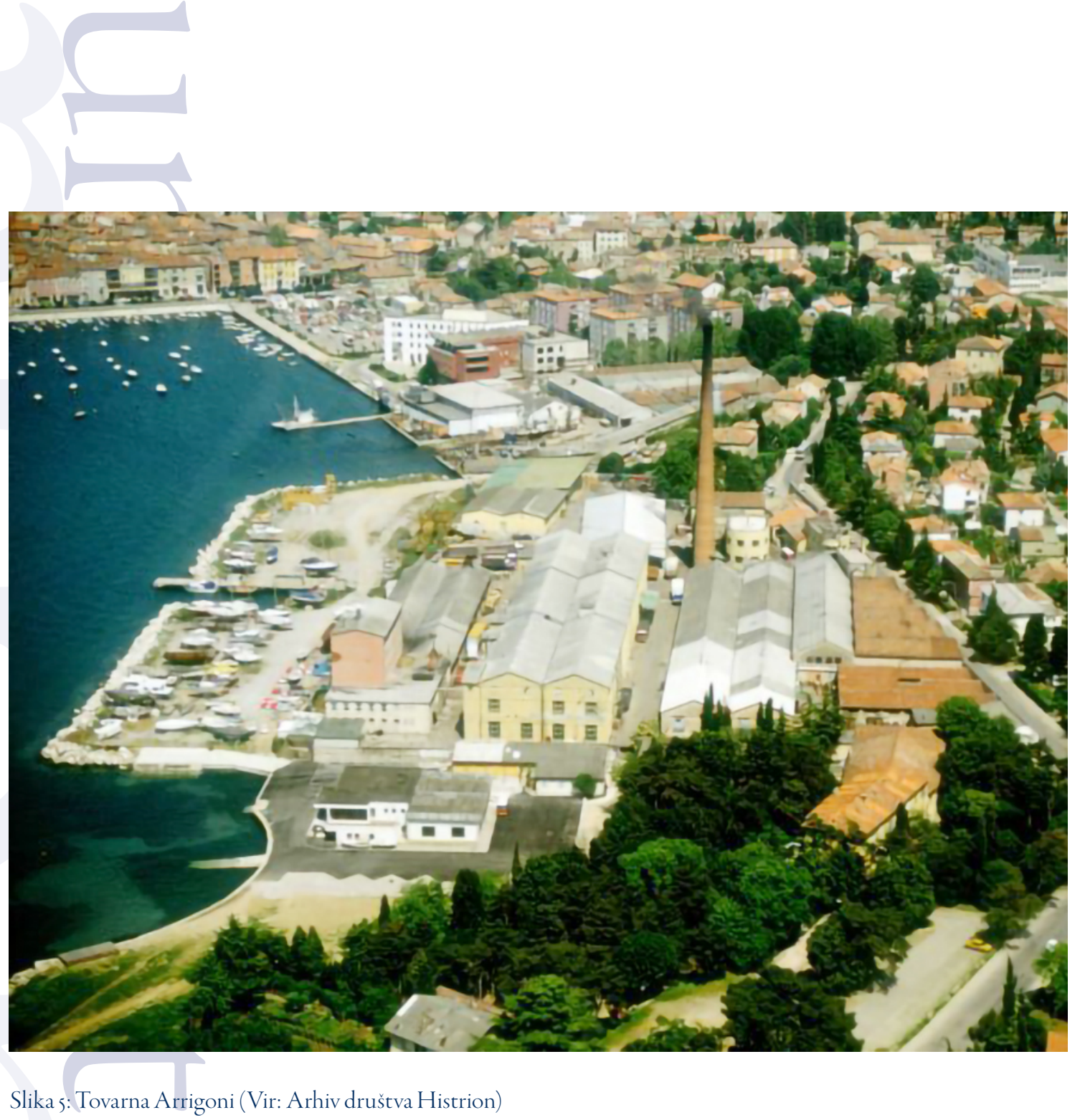

la neprofitabilno in $\mathrm{z}$ večletnim finančnim deficitom (Kramar 1992, 178).

Petdeseta leta so prinesla nove spremembe. Leta 1954 je bil z Italijo podpisan Londonski memorandum in cona B je dokončno pripadala socialistični Jugoslaviji. V istem letu je tovarna Arrigoni zaposlovala 547 delavcev (Terčon 2013, I25). Svoje, še danes v spominu zelo živo ime, je dobila leta 1958 , ko je bila preimenovana $v$ tovarno Argo. Proizvodnja je bila še vedno usmerjena $\mathrm{v}$ predelavo sveže in slane ribe, zelenjave ter izdelovanje paradižnikove mezge in jušnih kock (Terčon 1989, 130).

Proti koncu petdesetih let dvajsetega stoletja, leta 1959, je bil ustanovljen Kombinat konzervne industrije Delamaris (KKID), v ka-

terem so se zaradi lažje organizacije proizvodnje in prodaje izdelkov združila podjetje Iris (kasnejši Delamaris), Argo, Ikra in Delamaris export-import. Argo je v sedemdesetih letih opustil predelavo rib in se preusmeril $\mathrm{v}$ predelavo in izdelavo ostalih živil (Volpi Lisjak 200I, I24). Argo je sčasoma postala blagovna znamka tovarne Droga. Konec sedemdesetih let dvajsetega stoletja je namreč tovarna prešla pod Drogo Portorož. V procesu tranzicije pa so prav to blagovno znamko prodali.

Kombinat je zaposloval 1285 delavcev, od tega je bilo 848 žensk (Egić 2016). Osemdeseta leta dvajsetega stoletja je skladno s politično nestabilnostjo in tranzicijo Slovenije iz socialističnega $\mathrm{v}$ demokratično-kapitalističen sistem 

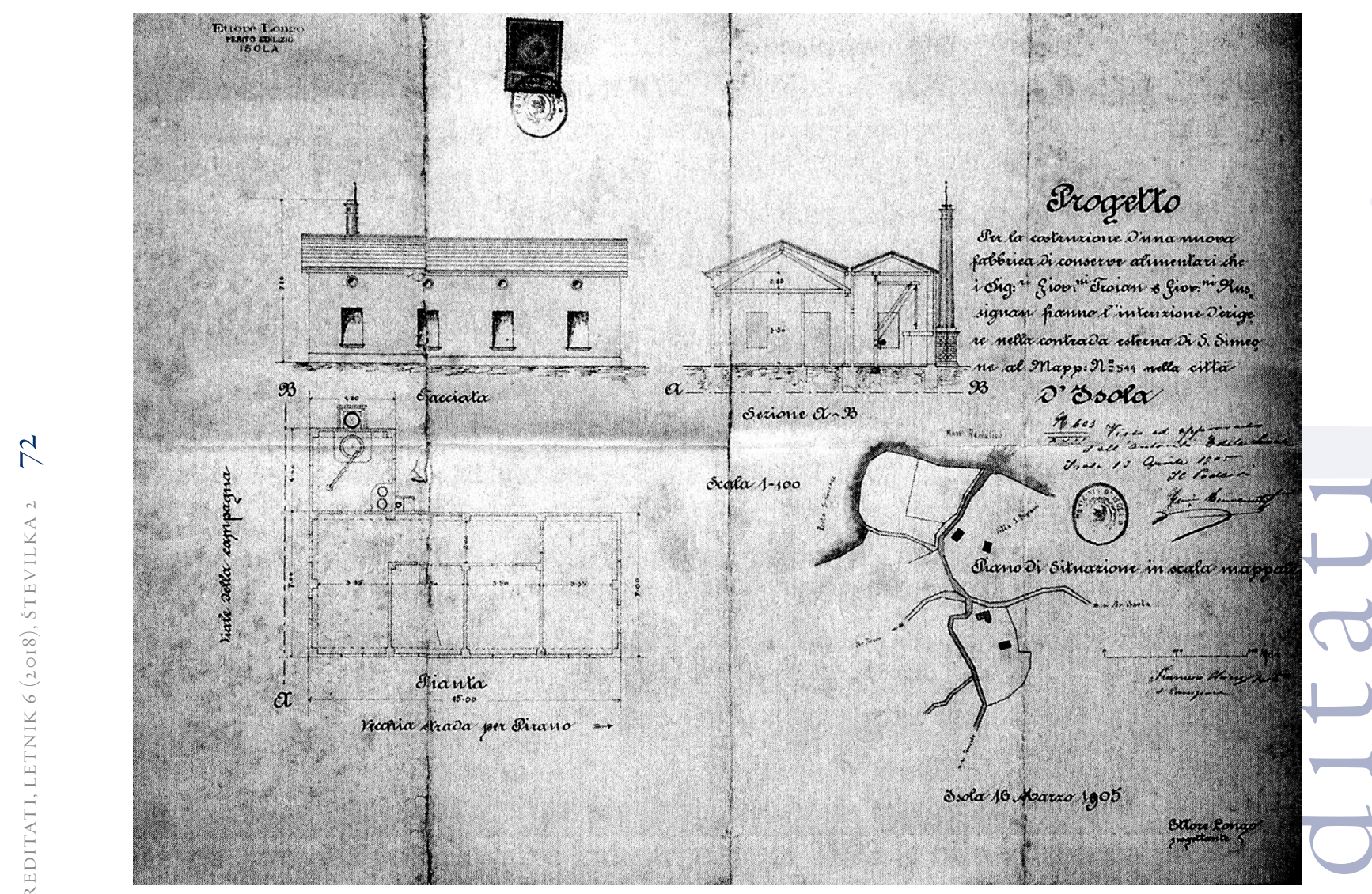

prišlo v Izoli do zatona ribje predelovalne industrije. Izguba skupnega jugoslovanskega trga, močna konkurenca trga zahodnih držav, zastarelost tehnologije, neučinkovito vodenje, večletni finančni deficit, ipd., so konec osemdesetih let dvajsetega stoletja pomenila konec obratovanja tovarne Arrigoni (Egić 2016). Danes nas na nekdanji prestiž tovarne opominjajo zgolj pripovedi iz spomina ter arhitekturni ostanki.

\section{Tovarna Troian}

Tovarna Troian je delovala med leti I88I in I9II pod imenom Giovanni Troian e Giovanni Russignani, skrajšano Troian \& CO (Terčon 1989 , I25; Terčon 2013, I2I). Leta 1920 je tovarno prevzela S. A. Conservifici in jo priključila $\mathrm{k}$ tovarni Arrigoni (Volpi Lisjak 200I, I38). Postavljena je bila v zahodnem zalivu mesta Izole pri San Simonu.

\section{Sklep}

Z oblikovanjem poti po lokacijah nekdanjih tovarn ribjih od vzhodnega do zahodnega dela Izole smo želeli prispevati $\mathrm{k}$ turistični ponudbi, ki ohranja kulturno dediščino, povezano $s$ prehrambno industrijo ribjih konzerv. Ribja predelovalna industrija je na severnem delu Jadranskega morja predstavljala velik delež $\mathrm{v}$ zaposlovanju ljudi, krojila je podobo kraja in $\mathrm{v}$ času Avstro-Ogrske je preskrbovala habsburški imperij $s$ »plavo « ribo, vse do Dunaja, Budimpešte, Prage in drugih velikih mest. Izolske tovarne so predstavljale del velikih proizvodnih verig in so skupaj še z nekaterimi drugimi tovar- 
nami v Istri predstavljale pomembne blagovne znamke. Prispevek opisuje zgodovino najpomembnejših tovarn ribjih konzerv, ki so še dokaj uspešno delovale tudi v času SFR Jugoslavije. Prikaže razvoj šestih tovarn, njihovo arhitekturno zasnovo, predstavi proizvodnje artikle in prikaže nekatere pomembne blagovne znamke. Tovarna Ampelea, pozneje Delamaris, je bilo eno najbolj uspešnih podjetij današnjega slovenskega Primorja, ki je od svojega začetka delovanja, postavljenega v leto 1879 in vse do selitve v Pivko, krojila življenjski ritem Izolanov in podobo vzhodnega dela mesta Izole. Danes na zlato obdobje te tovarne opozarja prazna propadajoča stavba $\mathrm{z}$ značilnim prenovljenim logotipom na tabli, ki stoji pri vhodu v dvorišče.

Tovarno Delise, ki se je nahajala v bližini Delamarisa, umeščamo med najkasneje postavljene obrate za predelavo hrane v Izoli, kot tudi med najmanjše. Postavljena je bila v dvajsetih letih prejšnjega stoletja in zaposlovala je zgolj devet delavcev. Delovala je krajši čas in je razmeroma slabo ohranjena v ustnem izročilu Izolanov, več pa o njej vedo lokalni ljubiteljski raziskovalci.

Tretjo največjo tovarno, tovarno Noerdlinger, ki je z malo manj kot devetdesetimi zaposlenimi predelovala bosanske slive $\mathrm{v}$ marmelado, sta postavila brata Noerdlinger na območju vzhodnega zaliva leta I884. Danes o njeni lokaciji pripovedujejo pretežno ljubitelji tehnične oziroma industrijske dediščine.

Tovarna Degrassi, kasneje Torrigiani, je predstavljala enega manjših obratov konzerviranja hrane v Izoli. Ustanovljena leta 1882 je tekom let zaposlovala manj kot sedemdeset oseb. Pozneje na tej lokaciji deluje podjetje Riba. Še danes se na tem mestu nahajajo stavbe in nekdanji škver, priročna ladjedelnica za vzdrževanje nekdaj številnega ribiškega ladjevja.

Prvi spomin na nekdanjo tovarno Arrigoni, poznejšo tovarno Droga, je zagotovo znana blagovna znamka »Argo juha«, poznejše generacije pa preverjeno poznajo paštete, ki so še danes spet $\mathrm{v}$ preoblikovani podobi znane kot paštete Argeta, na dobri strani kruha. Na nekdaj veličastno tovarno Arrigoni, spominjajo ruševine z dimnikom, ki po mnenju nekaterih kvarijo podobo marine, po mnenju drugih pa pričajo o velikem pomenu tega nekdanjega obrata.

O tovarni Troian ni veliko zapisanega. Postavljena je bila leta i88I nekje na območju San Simona - Simonovega zaliva, po prvi svetovni vojni pa je bila tudi ta proizvodnja priključena $\mathrm{k}$ tovarni Arrigoni. Lokacija tovarne ni natančno znana, ve pa se, da je stala $v$ omenjenem zalivu. Ker večina še obstoječih stavb nekdanjih industrijskih obratov neslavno propada in vzbuja pri obiskovalcih bodisi zgražanje bodisi radovednost, smo se odločili, da z oblikovano potjo tovarn poskušamo doseči, da se nekdanji družbeni spomin ohranja kot dediščina in da sloves nekdanjega ribiškega mesta iztrgamo pozabi.

\section{Summary}

The trail of factories is a short, almost three kilometres long tourist route which seeks to preserve the memory of fish canning factories and the food processing industry, the once leading industry in Izola, formerly known as a fishermen's and workers' town. A keen observer can discern the factory buildings set in the coastal landscape on the former outskirts of Izola, where the coastal strip is lined with now abandoned spacious halls, or more or less poorly preserved buildings or plain ruins. The memory of the factories in their operating days is kept in both the coastal landscape and Izolans' narratives. The purpose of this article is to present the reader with the Trail of Factories or the story written by the economic activity of the fish processing industry in the seaside town, which began in the last quarter of the nineteenth century and continues to the present day. The trail talks about the history that persists in the memory of the local inhabitants as well as lives on and represents the past operations of Izola's six factories lining the bay from the western to the eastern part of the town. The two extremes of the described route coincide with the processing of forage fish, which used to be Izola's primary economic activity. Strategically set on the shoreline, the factories' locations allowed for a speedy processing of the catch. For transport, fishing vessels and sea waterways were mainly used. From the architectural point of view, the 
three major factories, Ampelea (Delamaris), Arrigoni (Argo or Droga) and Degrassi (later Riba), are situated outside the old town and are still visible in Izolas zoning plan. Well located, the abandoned factory buildings are now interesting for capital investment and have been the object of successive resales due to a failed transition and misuse of former collective property. The article was written within the framework of the Student Innovation Project for Social Benefit (ŠIPK) - Fish on the Way, Fish Showing the Way: The Heritage of Fisheries and the Processing Industry with an Emphasis on Izola, which was carried out from March to June 2018. The aim of the project was to teach strollers enjoying Slovenian coastal landscapes about the cultural heritage associated with the fish processing industry and fisheries. By creating trails along the locations of the former fish canning factories from the eastern to the western part of Izola, actors wanted to contribute to the tourist offer, which preserves the cultural heritage associated with fisheries and the fish processing industry. In the northern part of the Adriatic Sea, the latter represented the main employer in the area; moreover, it shaped the image of the place and, during the Austro-Hungarian period, supplied the Habsburg Empire with forage fish all the way to Vienna, Budapest, Prague and other major cities. Izola's factories were part of large production chains and, together with some other factories in Istria, represented important brands. The article describes the history of the most important food processing industries and fish canning factories that, while still quite successful in the SFR Yugoslavia, were mostly blighted following Slovenia's independence and its transition to neoliberal capitalism. The article presents the development of six town factories, their architectural frame, production lines, and some important brands. One of the most successful companies of today's Slovenian Primorje, the Ampelea factory (later Delamaris) shaped the life of Izolans and formed the image of the eastern part of the town since 1879 , when the factory commenced its operations, and until it moved to Pivka. The golden period of the factory is evoked by abandoned and decomposing buildings with a distinctive renewed logo on the board standing at the entrance to the yard. The other factory, Delise, was opened in 1920, in the immediate vicinity of the first one. It is known as one of the smallest as it employed only nine workers and operat- ed for a short time. While the memory and oral history of the factory are not well kept among the local population, this gap is bridged by amateur researchers. The third largest factory, the Noerdlinger plant, where Bosnian plums were made into jam by less than ninety employees, was set up by the Noerdlinger brothers in the eastern section of the bay in 1884 . Today, this factory and its location are kept in oral histories of amateur researchers interested in technical or industrial heritage. Another in the series of minor food processing plants in Izola was the Degrassi (later Torrigiani) plant. Established in I882, it employed less than seventy persons over the years. Later on, the building complex housed the Riba company, known primarily for its fishing fleet. Even today, there are buildings and a former škver, a convenient shipyard, where the once-substantial fishing fleet was maintained. The first memory of the former Arrigoni (later Droga) factory is certainly the famous brand of "Argo soup", while the subsequent generations are more familiar with its pates, which are today revived as Argeta pate, with the slogan On the good side of bread.

What remains of the Arrigoni factory is its dilapidated buildings and a chimney, which, according to some, spoil the image of the marina and, according to others, testify to the great importance of this once magnificent plant. Little is written about the Troian factory as well. It was set up in 188I somewhere in the San Simon area and incorporated into the Arrigoni factory after World War I. Troian's location is not well known, but it is believed to have stood in the San Simon bay. Most of the existing buildings of former industrial plants are collapsing, triggering excitement of visitors, whether the ruins are seen as scandalous or feed the curiosity of walkers. Due to this fact, the authors of the project decided to transmit the former social memory as a legacy or cultural heritage, in the belief that the reputation of the former fishing town should not be consigned to oblivion.

\section{Viri in literatura}

Kramar, J. 1987. Izola: mesto ribičev in delavcev. Koper: Založba Lipa.

Kramar, J. 1992. »Ribja industrija v Izoli v letih od 1945-1954《. Annales no. 2: 175-182.

Egić, G. 2016. Ribja predelovalna industrija v Izoli. Diplomsko delo. Ljubljana: Univerza v Ljubljani - Filozofska fakulteta, Oddelek 
za zgodovino, http://zgodovina.si/ribjapredelovalna-industrija-v-izoli-4-delobdobje-po-drugi-svetovni-vojni/.

Terčon, N. 1989. »Razvoj industrijskega ribištva na slovenski obali v letih 1945-1959《, Kronika časopis za slovensko krajevno zgodovino 37 (I/2): I23-I35, https://www.dlib.si/details/ URN:NBN:SI:DOC-Q०OQIO॰G/?euapi $=\mathrm{I} \&$ quer $\mathrm{y}=27 \mathrm{keyword} \% 3 \mathrm{dnadja}+$ ter $\% \mathrm{C}_{4}$ $\% 8$ Don\%27\&pageSize $=25$.

Terčon, N. 2013. Vzpostavitev slovenskega pomorstva 1945-1958. Doktorska disertacija. Koper: Univerza na Primorskem, Fakulteta za humanistične študije.

Tomšič, D. 2002. »10235 Izola: Tovarna Droga«. V: Zgodnja industrijska arbitektura na Slovenskem : vodnik po arhitekturi, urednica Damjana Prešeren, I3I-I36. Ljubljana: Zavod za varstvo kulturne dediščine.

Volpi Lisjak, B. 200ı. »Ženska delovna sila v ribjih tovarnah v Izoli in Kopru. Konzerviranje in soljenje rib, $\ll$ Annales, Series Historia et Sociologia II (24): 135-I50, https://www.dlib.si/details/ URN:NBN:SI:DOC-MDBSIXVP/?euapi= $\mathrm{I} \&$ query=\%27keywords\%3dvolpi+lisjak\%2c +bruno\%27\&pageSize.

Intervju s Srečkom Gombačem ( $\mathrm{z}$ antropologinjo Alenko Janko Spreizer). Intervju. $\mathrm{MP}_{4}$ datoteka. Arhiv društva Histrion (25. 02. 2015). 